\title{
Risk Management Model using Cause and Effect Analysis in Industrial Building Project
}

\author{
Oki Oktaviani ${ }^{1}$, Budi Susetyo ${ }^{2}$, Bambang Purwoko Kusumo Bintoro ${ }^{3}$ \\ ${ }^{1}$ Postgraduate Student of Master Civil Engineering, Universitas Mercu Buana, Jakarta, Indonesia, \\ ${ }^{2}$ Lecturer of Master Civil Engineering, Universitas Mercu Buana, Jakarta, Indonesia, \\ ${ }^{3}$ Lecturer of Master Civil Engineering, Universitas Bakrie, Jakarta, Indonesia
}

Corresponding Author: Oki Oktaviani

\begin{abstract}
The purpose of this study is to determine the main potential risks that occur in the design planning stage of a construction project, especially in an Industrial Building project. Based on the available literature and the experiences of other authors and practitioners, a list of potential risks was developed. Risks events were initially categorized into technical, project management, commercial and external categories. Risks are evaluated by professional practitioners who have experience in construction projects. The evaluation includes the expected likelihood of the event and its impact on changes in scope of work. This study considers each risk among owners, consultants, contractors and others. The data collected were analyzed qualitatively and quantitatively to assess the severity and impact of the event. The recommended responses to major risks are introduced in this study.
\end{abstract}

Keywords: risk management model, planning stage, industrial building

\section{INTRODUCTION}

Risk assessments are necessary to anticipate and prevent accidents from occurring or repeating (Lough, K. G. et al., 2007). Risk event from a different project is different from the risk event on another project. Likewise, the level of occurrence and impact in each project is always changing from one project to another. This makes it difficult for management to handle risks on new projects. Lack of risk management, even inadequate risk analysis, can put construction projects in jeopardy (Basari, I., 2017). According to research by (Awuni, M.A., 2019) revealed that from the 114 consultants only had minimal knowledge about the implementation of risk management at the planning stage. Many respondents know the theoretical knowledge of risk management and its application at the planning stage. There are also many studies that examine risk management at the construction stage or development stage. However, there are rarely studies that discuss risk management at the planning stage. Whereas at this stage most of the major decisions are made which will later affect the success of a construction project. Therefore, this research is very important in order to know the negative impact due to the lack of implementation of risk management at the planning stage.

Construction Project is a process where activity includes different risks that must be handled by all project actors. The planning stage is the initial part of a development project where the project solution is selected from a variety of competitive alternatives that meet the project requirements. This is the stage where the risks associated with a decision can have an impact on the success of a project. In order to minimize the negative consequences of decisions made during the planning stage and to achieve the benefits of the actions taken, appropriate risk management should be used from the early stages of a development project. However, it 
is common nowadays that the risks in the decision making stage are not considered by project actors in depth, because the capabilities in risk identification, risk assessment and risk management have not been fully developed. Most of the knowledge and experiences of project actors are used in the realization of project development but are rarely associated with risks in decision making or planning. New development projects are not always considered unique and their routines and work schemes accumulate form previous projects without considering the risk and the need for innovation to make the final solution more specific and competitive. Each stage requires good decisions to take further steps towards project success. The negative consequences of decision making will impact several stages of the project. Therefore, risk management is a very important thing to do in a construction project.

\section{LITERATURE REVIEW \\ Construction Project}

Construction project is a process where several groups of people work on the development on buildings from concept to development. The project is divided into several stages where the project actors focus on development according to the roles or responsibilities that have been determined.

According to (Chan, A.P.C. and Chan, A.P.L., 2004), construction projects have many often conflicting objectives that must be met in order for a project to be considered a success. Project goals are dynamic, and success means different things to people at different points in the project life cycle.

\section{Risk Management}

According to (Djohanputro, B., 2008) risk management is a structured and systematic process in identifying, measuring, mapping, developing alternative risk management, and monitoring and controlling risk management. Risk management is the art and science of anticipating and planning for future uncertain events. It is concerned with identifying and analyzing a range of possible outcomes, then control and mitigate their negative impacts. The objective is to understand, and mitigate or control risks (Sakthiniveditha, V., 2015).

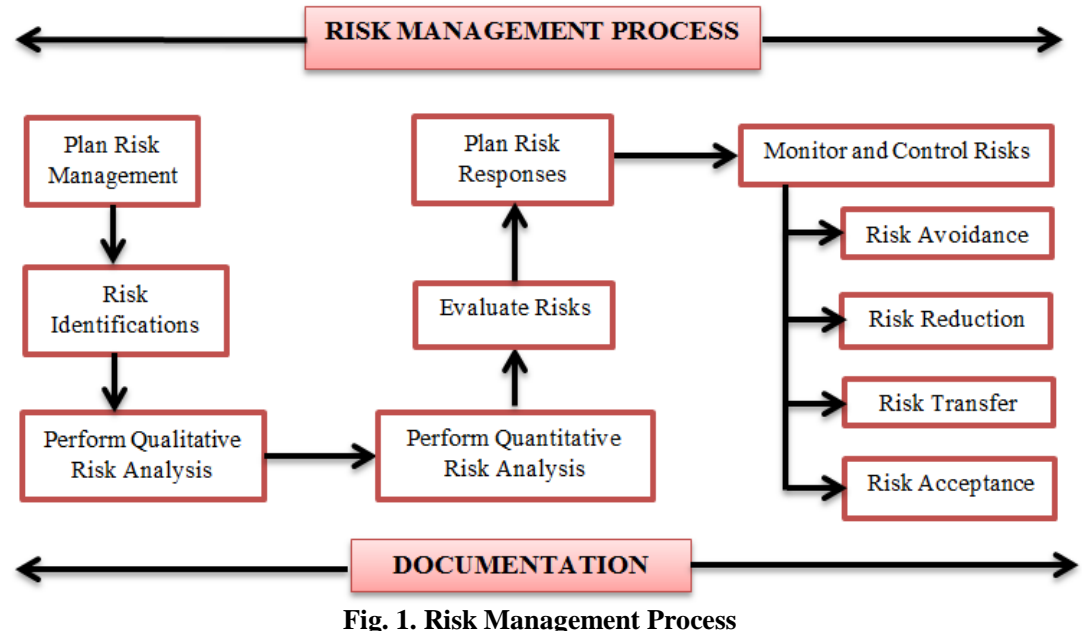

Risk Assessment

Table 1. Probability Scale (AS/NZS 4360 : Risk Management, 2004)
\begin{tabular}{|l|l|l|}
\hline Level & Occurence & Description \\
\hline $\mathbf{1}$ & Very Unlikely & Almost never happen \\
\hline $\mathbf{2}$ & Unlikely & Possible, but rare \\
\hline $\mathbf{3}$ & Possible & Can occur under certain condition \\
\hline $\mathbf{4}$ & Likely & Can happen periodically \\
\hline $\mathbf{5}$ & Almost Certain & Can happen anytime \\
\hline
\end{tabular}


Table 2. Severity Scale (Anitasari \& Wessiani, 2011)

\begin{tabular}{|l|l|l|}
\hline Level & Impact & Description \\
\hline $\mathbf{1}$ & Insignificant & Low financial loss \\
\hline $\mathbf{2}$ & Minor & First aid treatment, medium financial loss \\
\hline $\mathbf{3}$ & Moderate & Medical treatment required, high financial loss \\
\hline $\mathbf{4}$ & Mayor & Extensive injuries, loss of production capability, major financial loss \\
\hline $\mathbf{5}$ & Catastrophic & Death, huge financial loss \\
\hline
\end{tabular}

Table 3. Risk Assessment Matrix (AS/NZS 4360 : Risk Management, 2004)

\begin{tabular}{|l|l|l|l|l|l|}
\hline \multirow{2}{*}{ Probability } & Consequences & \multicolumn{5}{|l|}{} \\
\cline { 2 - 6 } & $\mathbf{1}$ (Insignificant) & $\mathbf{2}$ (Minor) & $\mathbf{3}$ (Moderate) & $\mathbf{4}$ (Mayor) & $\mathbf{5}$ (Catastrophic) \\
\hline 1 (Very Unlikely) & LOW & LOW & LOW & LOW & MEDIUM \\
\hline 2 (Unlikely) & LOW & LOW & MEDIUM & MEDIUM & MEDIUM \\
\hline 3 (Possible) & LOW & MEDIUM & MEDIUM & MEDIUM & HIGH \\
\hline 4 (Likely) & MEDIUM & MEDIUM & MEDIUM & HIGH & HIGH \\
\hline 5 (Almost Certain) & MEDIUM & MEDIUM & HIGH & HIGH & HIGH \\
\hline
\end{tabular}

\section{Cause and Effect Analysis}

Cause and Effect Analysis is a structured method to identify the possible risk of complex problems that present several interrelated causes (Lorenada, E.M., 2017). This method classifies the causes of a risk into categories to facilitate identification. This cause information is shown in a fishbone diagram or an Ishikawa diagram. For building a fishbone chart we use arrows or branches: (1) primary branch: represents the effect, (2) major branch: corresponds to the major cause, (3) minor branch: corresponds to the causative and more detailed factors.

\section{MATERIALS \& METHODS}

The research is focus on the risks posed by lack of knowledge or not applying risk management at the planning stage. The purpose of this research is to find the most potential risks that occur in the planning stage of a construction project, especially in the Industrial Building Project.

The risk is evaluated by professional practitioners who have experience in construction projects. The evaluation includes the expected probability of the event and is impact on changes in the scope of work. This study considers each risk among owners, consultants, contractors and others. The data collected is analyzed qualitatively and quantitatively to assess the severity and impact of the event.

The potential risks were identified by the authors based on the available published researches and the interview carried out with experts. The risks were categorized from the Risk Breakdown Structure (PMBOK 6th Edition, 2017) in four major groups, including:

Table 4. Risk Factor in Industrial Project

\begin{tabular}{|c|c|c|c|c|}
\hline Main Factor & Categories & Variable & Sub Factor & Reference \\
\hline \multirow{6}{*}{$\begin{array}{l}\text { Technical } \\
\text { Risk (X1) }\end{array}$} & \multirow{3}{*}{ Process } & $\mathrm{X} 1.1$ & Site Investigation & Sutoyo (2000) \\
\hline & & $\mathrm{X} 1.2$ & Completeness data of the site conditions & Muhharam Noor (2006) \\
\hline & & $\mathrm{X} 1.3$ & $\begin{array}{l}\text { Completeness of data to make DED (Detail Engineering } \\
\text { Design) }\end{array}$ & Documment reviews \\
\hline & \multirow{2}{*}{ Design } & $\mathrm{X} 1.4$ & Error in design & Candra Y. (2017) \\
\hline & & $\mathrm{X} 1.5$ & Completeness of DED & CII (1997) \\
\hline & Technology & $\mathrm{X} 1.6$ & Error due to software used & Hosen (2006) \\
\hline \multirow{13}{*}{$\begin{array}{l}\text { Project } \\
\text { Management } \\
\text { Risk (X2) }\end{array}$} & Scheduling & $\mathrm{X} 2.1$ & Limited time to prepare for tender & Ogulana (2003) \\
\hline & \multirow{2}{*}{ Estimate } & $\mathrm{X} 2.2$ & Material specification that are less detailed and less accurate & Soeharto (1997) \\
\hline & & $\mathrm{X} 2.3$ & BOQ calculation that is not accurate & Wideman (1992) \\
\hline & Planning & $\mathrm{X} 2.4$ & $\begin{array}{l}\text { Inconsistency between construction plans and field } \\
\text { implementation }\end{array}$ & Ali K. (2017) \\
\hline & \multirow{4}{*}{ Communication } & $\mathrm{X} 2.5$ & Lack of coordination between engineering team & G. B. Oberlander (1993) \\
\hline & & $\mathrm{X} 2.6$ & Lack of coordination between design team & Vichian \\
\hline & & $\mathrm{X} 2.7$ & Lack of coordination between several disciplines & Karim El-Dash (2006) \\
\hline & & $\mathrm{X} 2.8$ & Communication between Owner and the design team & Muhammad Saqib (2008) \\
\hline & \multirow{4}{*}{ Resources } & $\mathrm{X} 2.9$ & Lack of Estimator's experience & Callahan MT (1992) \\
\hline & & $\mathrm{X} 2.10$ & Lack of designer's experience & Wideman (1992) \\
\hline & & $\mathrm{X} 2.11$ & Lack of Engineer's experience & Ogulana (2003) \\
\hline & & $\mathrm{X} 2.12$ & There are no consultants for special disciplines & Karim El-Dash (2006) \\
\hline & Prioritization & $\mathrm{X} 2.13$ & No quality control system & Karim El-Dash (2006) \\
\hline
\end{tabular}




\begin{tabular}{|c|c|c|c|c|}
\hline \multicolumn{5}{|c|}{ Table 4 Continued... } \\
\hline \multirow{5}{*}{$\begin{array}{l}\text { Commercial } \\
\text { Risk (X3) }\end{array}$} & Subcontractors & $\mathrm{X} 3.1$ & Contractor's experience & C. K Ho (2001) \\
\hline & \multirow{2}{*}{ Suppliers } & $\mathrm{X} 3.2$ & Machine vendor/ supplier change & Documment reviews \\
\hline & & $\mathrm{X} 3.3$ & Change in the shape, size, location of the machine & Documment reviews \\
\hline & \multirow{2}{*}{$\begin{array}{l}\text { Client/ } \\
\text { Customers }\end{array}$} & $\mathrm{X} 3.4$ & Design changes by Owner (addition / subtraction) & Karim El-Dash (2006) \\
\hline & & $\mathrm{X} 3.5$ & Owner doesn't fully explain his needs & Anik R. (2018) \\
\hline \multirow{5}{*}{$\begin{array}{l}\text { External Risk } \\
(\mathrm{X} 4)\end{array}$} & \multirow{3}{*}{ Regulatory } & $\mathrm{X} 4.1$ & $\begin{array}{l}\text { Inflation and price fluctuations that cause cost overruns from } \\
\text { the original plan }\end{array}$ & Yu Sun (2008) \\
\hline & & $\mathrm{X} 4.2$ & Industry standard compliance & CII (1997) \\
\hline & & $\mathrm{X} 4.3$ & $\begin{array}{l}\text { Change in the government's political and economic situation } \\
\text { or policies }\end{array}$ & Muhammad Saqib (2008) \\
\hline & \multirow{2}{*}{ Market } & $\mathrm{X} 4.4$ & & Anik R. (2008) \\
\hline & & $\mathrm{X} 4.5$ & Increase in labor costs, material price and equipment price & Gusti A.(2015) \\
\hline \multirow{2}{*}{$\begin{array}{l}\text { Cost Factor } \\
\text { (Y) }\end{array}$} & \multirow{2}{*}{ Cost Efficiency } & Y1 & Application of Value Engineering & Karim El-Dash (2006) \\
\hline & & $\mathrm{Y} 2$ & Application of Lean Construction & Documment reviews \\
\hline
\end{tabular}

The table above is a list of risk factor that will be tested for expert validity and carried out a pilot survey before a questionnaire is made and distributed to respondents.

\section{RESULT}

From the results of statistical analysis, a finding will be obtained in this study. In the research process, standards were achieved based on secondary data analysis which was translated into research variables will be the basis and reference for obtaining results from primary data (questionnaire) so that the objectives of the research can be achieved. Data processing for the results of the questionnaire survey was analyzed using SPPS version 25 software.

\section{Statistical Analysis \\ Validity and Reliability Test}

The r-table value with a significance level used 5\% obtained r-table Product Moment $\mathrm{df}=31-2=0.355$. The validity test results of the factors causing change orders on time and cost performance show valid variables because of the value of r-table > 0.355 .

The reliability test in this study uses the internal reliability coefficient of alpha, the questionnaire questions can be said to be reliable if the Cronbach's Alpha coefficient is above 0,6. The results of the reliability test can be seen in the table below:

Table 5. SPSS reliability test Case Proccesing Summary Case Processing Summary

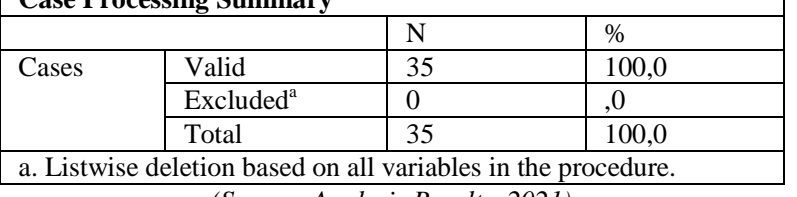

(Source. Analysis Results, 2021)

Table 6. SPSS reliability test Reliability Statistics Reliability Statistics

\begin{tabular}{|l|l|}
\hline Cronbach's Alpha & N of Items \\
\hline
\end{tabular}

\begin{tabular}{l|l}
,918 & 31 \\
\hline \multicolumn{2}{l}{ (Source. Analysis Results, 2021) }
\end{tabular}

Reliability testing was processed using the Statistical Package for Social Science (SPSS) software. The results of the reliability test on the risk factors are 0.918, as in table 3 . Therefore, $0.903>0.60$ so that the questionnaire instrument is valid.

\section{Multinomial Logistic Regression Test}

The multinomial logistic regression test is a regression model used to solve regression cases with the dependent variable in the form of multinomial with one or more independent variables.

Indicator:

$$
P \text {-value }<\alpha(0,05)
$$

Table 7. SPSS Regression Multinomial Logistic Test Result X1 and Y

\begin{tabular}{|l|l|l|l|l|}
\hline Model Fitting Information \\
\hline \multirow{2}{*}{ Model } & Model Fitting Criteria & Likelihood Ratio Tests \\
\cline { 2 - 5 } & -2 Log Likelihood & Chi-Square & df & Sig. \\
\hline Intercept Only & 70,193 & & & \\
\hline Final & 33,641 & 36,552 & 14 &, 001 \\
\hline
\end{tabular}

(Source. Analysis Results, 2021) 
Table 8. SPSS Regression Multinomial Logistic Test Result X2 and Y Model Fitting Information

\begin{tabular}{|l|l|l|l|l|}
\hline \multirow{2}{*}{ Model } & Model Fitting Criteria & \multicolumn{4}{|c|}{ Likelihood Ratio Tests } \\
\cline { 2 - 5 } & $\mathbf{- 2 ~ L o g ~ L i k e l i h o o d ~}$ & Chi-Square & df & Sig. \\
\hline Intercept Only & 70,193 & & & \\
\hline Final &, 000 & 70,193 & 28 &, 000 \\
\hline
\end{tabular}

(Source. Analysis Results, 2021)

Table 9. SPSS Regression Multinomial Logistic Test Result X3 and Y Model Fitting Information

\begin{tabular}{|l|l|l|l|l|}
\hline Model Fitting Information \\
\hline \multirow{2}{*}{ Model } & Model Fitting Criteria & \multicolumn{4}{|l|}{ Likelihood Ratio Tests } \\
\cline { 2 - 5 } & $\mathbf{- 2 ~ L o g ~ L i k e l i h o o d ~}$ & Chi-Square & df & Sig. \\
\hline Intercept Only & 71,988 & & & \\
\hline Final & 32,573 & 39,415 & 15 &, 001 \\
\hline
\end{tabular}

(Source. Analysis Results, 2021)

Table 10. SPSS Regression Multinomial Logistic Test Result X4 and Y

\begin{tabular}{|c|c|c|c|c|}
\hline \multicolumn{5}{|c|}{ Model Fitting Information } \\
\hline \multirow[t]{2}{*}{ Model } & \multirow{2}{*}{$\begin{array}{l}\text { Model Fitting Criteria } \\
\text {-2 Log Likelihood }\end{array}$} & \multicolumn{3}{|c|}{ Likelihood Ratio Tests } \\
\hline & & Chi-Square & df & Sig. \\
\hline Intercept Only & 77,169 & & & \\
\hline Final & 48,609 & 28,560 & 15 & ,018 \\
\hline
\end{tabular}

(Source. Analysis Results, 2021)

Table 11. Risk Level Assessment

\begin{tabular}{|c|c|c|c|c|}
\hline Main Factor & Variable & Risk Factor & Means & $\begin{array}{l}\text { Risk } \\
\text { Level }\end{array}$ \\
\hline \multirow{6}{*}{$\begin{array}{l}\text { Technical Risk Factor } \\
\text { (X1) }\end{array}$} & $\mathrm{X} 1.1$ & Site Investigation & 17,6 & $\mathrm{H}$ \\
\hline & $\mathrm{X} 1.2$ & Completeness data of the site conditions & 19,4 & $\mathrm{H}$ \\
\hline & $\mathrm{X} 1.3$ & Completeness of data to make DED (Detail Engineering Design) & 17,4 & $\mathrm{H}$ \\
\hline & $\mathrm{X} 1.4$ & Error in design & 17,8 & $\mathrm{H}$ \\
\hline & $\mathrm{X} 1.5$ & Completeness of DED (Detail Engineering Design) & 18,2 & $\mathrm{H}$ \\
\hline & $\mathrm{X} 1.7$ & Error due to software used & 10,1 & $\mathrm{~L}$ \\
\hline \multirow{13}{*}{$\begin{array}{l}\text { Project } \\
\text { Factor } \\
\text { (X2) }\end{array}$} & $\mathrm{X} 2.1$ & Limited time to prepare for tender & 17,5 & $\mathrm{H}$ \\
\hline & $\mathrm{X} 2.2$ & Material specification that are less detailed and less accurate & 15,2 & M \\
\hline & $\mathrm{X} 2.3$ & BOQ calculation that is not accurate & 15,5 & M \\
\hline & $\mathrm{X} 2.5$ & $\begin{array}{l}\begin{array}{l}\text { Inconsistency between } \\
\text { implementation }\end{array} \\
\text { imstruction plans and field }\end{array}$ & 18,3 & $\mathrm{H}$ \\
\hline & $\mathrm{X} 2.6$ & Lack of coordination between engineering team & 16,0 & M \\
\hline & $\mathrm{X} 2.7$ & Lack of coordination between design team & 14,7 & M \\
\hline & $\mathrm{X} 2.8$ & Lack of coordination between several disciplines & 15,6 & M \\
\hline & $\mathrm{X} 2.9$ & Communication between Owner and the design team & 16,3 & $\mathrm{M}$ \\
\hline & $\mathrm{X} 2.10$ & Lack of Estimator's experience & 12,9 & $\mathrm{~L}$ \\
\hline & $\mathrm{X} 2.11$ & Lack of designer's experience & 15,1 & M \\
\hline & $\mathrm{X} 2.12$ & Lack of Engineer's experience & 15,8 & $\mathrm{M}$ \\
\hline & $\mathrm{X} 2.13$ & There are no consultants for special disciplines & 12,2 & $\mathrm{~L}$ \\
\hline & $\mathrm{X} 2.14$ & No quality control system & 17,2 & $\mathrm{H}$ \\
\hline \multirow{5}{*}{$\begin{array}{l}\text { Commercial Risk Factor } \\
\text { (X3) }\end{array}$} & X3.1 & Contractor's experience & 13,4 & $\mathrm{~L}$ \\
\hline & $\mathrm{X} 3.2$ & Machine vendor/ supplier change & 18,7 & $\mathrm{H}$ \\
\hline & $\mathrm{X} 3.3$ & Change in the shape, size, location of the machine & 19,6 & $\mathrm{H}$ \\
\hline & X3.4 & Design changes by Owner (addition / subtraction) & 20,4 & $\mathrm{H}$ \\
\hline & X3.5 & Owner doesn't fully explain his needs & 16,9 & M \\
\hline \multirow{5}{*}{$\begin{array}{l}\text { External Risk Factor } \\
\text { (X4) }\end{array}$} & $\mathrm{X} 4.1$ & $\begin{array}{l}\text { Inflation and price fluctuations that cause cost overruns from the } \\
\text { original plan }\end{array}$ & 13,1 & $\mathrm{~L}$ \\
\hline & $\mathrm{X} 4.2$ & Industry standard compliance & 14,0 & M \\
\hline & $\mathrm{X} 4.3$ & $\begin{array}{l}\text { Change in the government's political and economic situation or } \\
\text { policies }\end{array}$ & 12,4 & $\mathrm{~L}$ \\
\hline & $\mathrm{X} 4.4$ & Lack of materials & 13,8 & M \\
\hline & $\mathrm{X} 4.5$ & Increase in labor costs, material price and equipment price & 13,5 & $\mathrm{~L}$ \\
\hline \multirow{2}{*}{$\begin{array}{l}\text { Cost Factor } \\
\text { (Y) }\end{array}$} & Y1 & Application of Value Engineering & 14,5 & $\mathrm{M}$ \\
\hline & Y2 & Application of Lean Construction & 16,2 & M \\
\hline
\end{tabular}

$$
\text { (Source. Analysis Results, 2021) }
$$

\section{CASE STUDY}

\section{Pareto Analysis}

At this stage, the work items are classified into similar work items and then sort them form the highest cost to the lowest cost in order to facilitate the research and a pareto distribution graph is made, by determining $80 \%$ of the total additional work as the root of the next analysis. 
Table 12. Change in scope of work

\begin{tabular}{|l|l|l|l|l|}
\hline No. & Work Item & Total Price & Percentage & Cumulative (\%) \\
\hline 1. & Creamer Tower & 4.104 .280 .809 & $27,14 \%$ & $27,14 \%$ \\
\hline 2. & Operational & 2.386 .881 .362 & $15,78 \%$ & $42,92 \%$ \\
\hline 3. & WTP, Carbon Tank \& GWT & 1.644 .610 .901 & $10,87 \%$ & $53,79 \%$ \\
\hline 4. & WWTP & 1.367 .572 .304 & $9,04 \%$ & $62,83 \%$ \\
\hline 5. & Instant Tower & 1.047 .279 .681 & $6,92 \%$ & $69,75 \%$ \\
\hline 6. & Boiler & 1.029 .031 .972 & $6,80 \%$ & $76,55 \%$ \\
\hline 7. & Chiller & 626.916 .656 & $4,14 \%$ & $80,69 \%$ \\
\hline 8. & Silo Debora & 551.683 .950 & $3,65 \%$ & $84,34 \%$ \\
\hline 9. & RAW Material Warehouse & 474.332 .216 & $3,14 \%$ & $87,48 \%$ \\
\hline 10. & Front Road MDC & 346.122 .471 & $2,29 \%$ & $89,77 \%$ \\
\hline 11. & Mosque \& Clinic & 289.043 .289 & $1,91 \%$ & $91,68 \%$ \\
\hline 12. & Panel Room \& Genset & 224.573 .458 & $1,48 \%$ & $93,16 \%$ \\
\hline 13. & STP & 211.580 .047 & $1,40 \%$ & $94,56 \%$ \\
\hline 14. & Office connecting ladder & 210.841 .247 & $1,39 \%$ & $95,95 \%$ \\
\hline 15. & Office & 155.564 .202 & $1,03 \%$ & $96,98 \%$ \\
\hline 16. & Guardhouse & 125.025 .987 & $0,83 \%$ & $97,81 \%$ \\
\hline 17. & Canteen & 120.762 .945 & $0,80 \%$ & $98,61 \%$ \\
\hline 18. & Utility & 91.254 .282 & $0,60 \%$ & $99,21 \%$ \\
\hline 19. & Gas \& Compressor Building & 52.664 .880 & $0,35 \%$ & $99,56 \%$ \\
\hline 20. & Operator room \& brigde & 35.854 .004 & $0,24 \%$ & $99,80 \%$ \\
\hline 21. & Forklift Track & 19.561 .112 & $0,13 \%$ & $99,93 \%$ \\
\hline 22. & Rotary Dryer & 9.334 .539 & $0,06 \%$ & $99,99 \%$ \\
\hline 23. & Flagpole & 534.053 & $0,001 \%$ & $\mathbf{1 0 0 \%}$ \\
\hline Total & & $\mathbf{1 1 . 8 3 4 . 9 8 2 . 0 7 0}$ & $\mathbf{1 0 0 \%}$ & \\
\hline & & & \\
\hline
\end{tabular}

From the table above, the Pareto Diagram has been carry out:

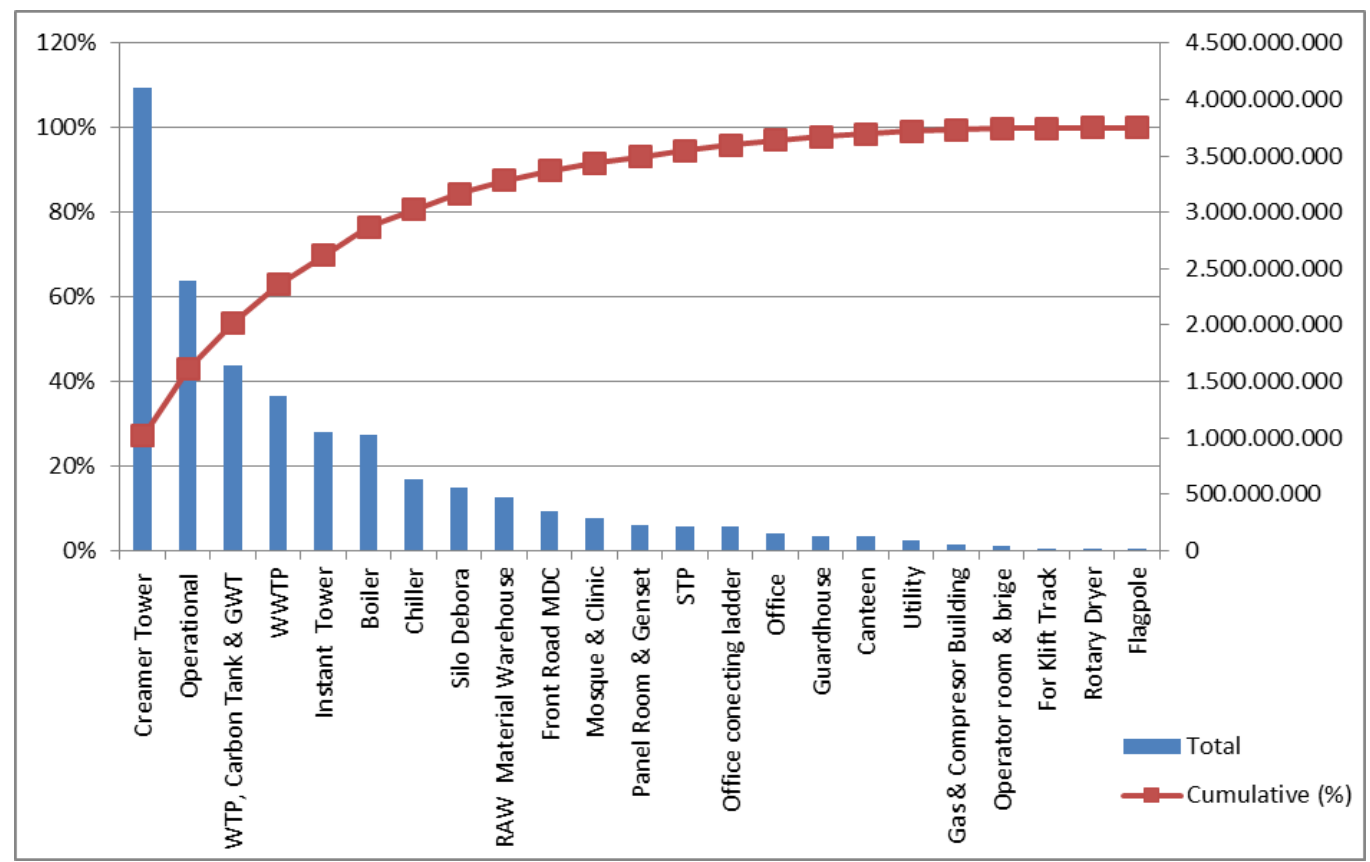

Fig. 2 Pareto Diagram

From the table above, 7 work items are selected that have significant influence on change scope of work, which will then be used in the analysis using a Cause and Effect diagram.

\section{Cause and Effect Analysis Method}

The following is a Cause and Effect diagram from a case study that has been carried out based on Pareto diagram. It can be seen that the main events greatly affect changes in the scope of work. Therefore, the Cause and Effect diagram is used to determine the cause of the event. 


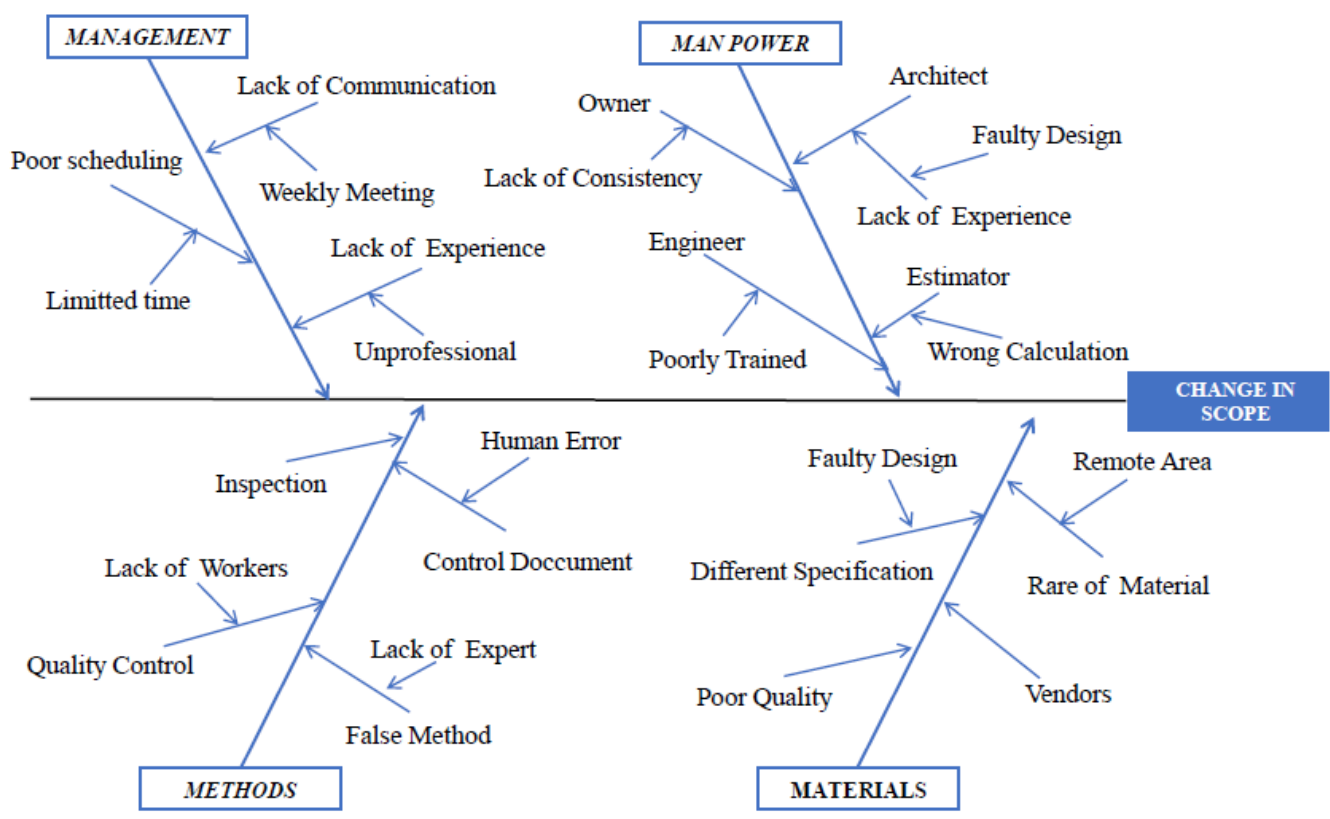

Fig. 3 Cause and Effect Diagram

From the Cause and Effect diagram above, it can be seen that the causes are risk factors that greatly affected in the change scopes of work. These risk factors become the dominant factors which will later be given preventive measures.

\section{DISCUSSION}

Risk Register

Table 12. Risk register

\begin{tabular}{|c|c|c|c|c|}
\hline $\begin{array}{l}\text { Risk } \\
\text { Level }\end{array}$ & Rank & Variable & Risk Factor & Risk Response \\
\hline \multirow{11}{*}{ High } & 1 & $\mathrm{X} 3.4$ & Design changes by Owner (addition / subtraction) & \multirow{11}{*}{ Risk Avoidance } \\
\hline & 2 & $\mathrm{X} 3.3$ & Change in the shape, size, location of the machine & \\
\hline & 3 & $\mathrm{X} 1.2$ & Completeness data of the site conditions & \\
\hline & 4 & $\mathrm{X} 3.2$ & Machine vendor/ supplier change & \\
\hline & 5 & $\mathrm{X} 2.5$ & Inconsistency between construction plans and field implementation & \\
\hline & 6 & $\mathrm{X} 1.5$ & Completeness of DED (Detail Engineering Design) & \\
\hline & 7 & $\mathrm{X} 1.4$ & Error in design & \\
\hline & 8 & $\mathrm{X} 1.1$ & Site Investigation & \\
\hline & 9 & $\mathrm{X} 1.3$ & Completeness of data to make DED (Detail Engineering Design) & \\
\hline & 10 & $\mathrm{X} 2.1$ & Limited time to prepare for tender & \\
\hline & 11 & $\mathrm{X} 2.14$ & No quality control system & \\
\hline \multirow{13}{*}{ Medium } & 12 & $\mathrm{X} 3.5$ & Owner doesn't fully explain his needs & \multirow{13}{*}{ Risk Reduction } \\
\hline & 13 & $\mathrm{X} 2.9$ & Communication between Owner and the design team & \\
\hline & 14 & $\mathrm{Y} 2$ & Appication of Lean Construction & \\
\hline & 15 & $\mathrm{X} 2.6$ & Lack of coordination between engineering team & \\
\hline & 16 & $\mathrm{X} 2.12$ & Lack of Engineer's experience & \\
\hline & 17 & $\mathrm{X} 2.8$ & Lack of coordination between several disciplines & \\
\hline & 18 & $\mathrm{X} 2.3$ & BOQ calculation that is not accurate & \\
\hline & 19 & $\mathrm{X} 2.2$ & Material specification that are less detailed and less accurate & \\
\hline & 20 & $\mathrm{X} 2.11$ & Lack of desainer's experience & \\
\hline & 21 & $\mathrm{X} 2.7$ & Lack of coordination between design team & \\
\hline & 22 & $\mathrm{Y} 1$ & Application of Value Engineering & \\
\hline & 23 & $\mathrm{X} 4.2$ & Industry standard compliance & \\
\hline & 24 & $\mathrm{X} 4.4$ & Lack of materials & \\
\hline \multirow{7}{*}{ Low } & 24 & $\mathrm{X} 4.5$ & Increase in labor costs, material price and equipment price & \multirow{7}{*}{$\begin{array}{l}\text { Risk Acceptance/ } \\
\text { Risk Transfer }\end{array}$} \\
\hline & 25 & $\mathrm{X} 3.1$ & Contractor's experience & \\
\hline & 27 & $\mathrm{X} 4.1$ & Inflation and price fluctuations that cause cost overruns from the original plan & \\
\hline & 28 & $\mathrm{X} 2.10$ & Lack of Estimator's experience & \\
\hline & 29 & $\mathrm{X} 4.3$ & Change in the government's political and economic situation or policies & \\
\hline & 30 & $\mathrm{X} 2.13$ & There are no consultants for special disciplines & \\
\hline & 31 & $\mathrm{X} 1.7$ & Error due to software used & \\
\hline
\end{tabular}

(Source. Analysis Results, 2021) 


\section{Risk Response}

From the results of the research using questionnaires and case study, it is found that several factors are very influential in the change in scope of work in
Industrial Building Project. And preventive measure should be taken for the dominant risk factor. The following is a table of dominant risk factor and how to prevent it.

Table 13. Dominant Risk Factor and Risk Response

\begin{tabular}{|c|c|c|}
\hline Variable & Dominant Risk Factor & Risk Response \\
\hline $\mathrm{X} 3.4$ & $\begin{array}{l}\text { Design changes by Owner (addition / } \\
\text { subtraction) }\end{array}$ & $\begin{array}{l}\text { At the time of planning, the project manager should make a list of what needs } \\
\text { are needed by the Owner to minimalize the design change. }\end{array}$ \\
\hline $\mathrm{X} 3.3$ & $\begin{array}{l}\text { Change in the shape, size, location of the } \\
\text { machine }\end{array}$ & $\begin{array}{l}\text { Ensure the specificatoins of the machine used are in accordance to the need } \\
\text { Conducting survey regarding the need of related machine }\end{array}$ \\
\hline $\mathrm{X} 1.2$ & Completeness data of the site conditions & $\begin{array}{l}\text { Conduct a site as detailed as possible } \\
\text { Remeasure the site }\end{array}$ \\
\hline $\mathrm{X} 3.2$ & Machine vendor/ supplier change & Ensure a trusted and familiar machine vendor or supplier \\
\hline $\mathrm{X} 2.5$ & $\begin{array}{l}\text { Inconsistency between construction plans } \\
\text { and field implementation }\end{array}$ & $\begin{array}{l}\text { Conduct weekly meeting to minimize change in the design } \\
\text { Design team should be someone who experienced in similar project }\end{array}$ \\
\hline $\mathrm{X} 1.5$ & $\begin{array}{l}\text { Completeness of DED (Detail Engineering } \\
\text { Design) }\end{array}$ & Make a list of DED to check after the drawings are complete \\
\hline $\mathrm{X} 1.4$ & Error in design & Implement a quality control system in each team \\
\hline $\mathrm{X} 1.1$ & Site Investigation & $\begin{array}{l}\text { Site survey must be carried out by the design team so that they can be more } \\
\text { accurate in making Detail Engineering Design }\end{array}$ \\
\hline $\mathrm{X} 2.1$ & $\begin{array}{l}\text { Completeness of data to make DED (Detail } \\
\text { Engineering Design) }\end{array}$ & $\begin{array}{l}\text { Ensure that all documents neeededfor planing are complete } \\
\text { Completing the missing data }\end{array}$ \\
\hline $\mathrm{X} 1.3$ & Limited time to prepare for tender & $\begin{array}{l}\text { Tender should not be prepare in a short time } \\
\text { Recruit more peope in the planning team }\end{array}$ \\
\hline $\mathrm{X} 2.14$ & No quality control system & $\begin{array}{l}\text { Make a quality control team } \\
\text { Require the Project Manager to carry out inspections }\end{array}$ \\
\hline
\end{tabular}

\section{CONCLUSION}

Based on the results of research and processing of secondary data, the conclusions can be drawn as follow:

1. From the results of the statistical tests, it is known that the most significant factors that affect change in scope of work in Industrial Building project are: (X2) project management risk factors and (X1) technical risk factors.

2. From the results of the risk assessment obtained 11 risk factors that have a high risk in influencing the change in scope of work in Industrial Building project, namely: (X3.4) Design changes by Owner, (X3.3) Change in the shape, size, location of the machine, (X1.2) Completeness data of the site conditions, (X3.2) Machine vendor/ supplier change, (X2.5) Inconsistency between construction plans and field implementation, (X1.5) Completeness of DED, (X1.4) Error in design, (X1.1) Site Investigation, (X2.1) Completeness of data to make DED, (X1.3) Limited time to prepare for tender, and (X2.14) No quality control system.
Form the results of the study, it can be concluded that the planning stage of a construction project, especially Industrial Building Project has very important influence in the change in scope of work. Therefore, risk management should be carried out as early as possible, namely at the planning stage.

\section{Acknowledgement: None}

\section{Conflict of Interest: None}

\section{Source of Funding: None}

\section{REFERENCES}

1. Lough, K. G. et al. (2007). The Risk in Early Design Method. Journal of Engineering Design.

2. Basari, Imayanti. (2107). Estimation Risk of High Rise Building on Contractor. IPTEK, Journal of Engineering.

3. Awuni, M. A. (2019). Risk Assessment at the Design Phase of Construction Projects in Ghana. Journal of Building Construction and Planning Research.

4. Chan, A.P.C. and Chan, A.P.L. (2004). Key Performance Indicators for measuring construction success. Benchmarking: An 
International Journal, Vol. 11 No. 2, pp. 203-221.

5. Djohanputro, Bramantyo. (2008). Manajemen Risiko Korporat. Jakarta: Penerbit PPM.

6. Sakthiniveditha, V. and, Pradeep, T. (2015). A Study On Risk Assessment In The Construction Of High-Rise Buildings. International Journal of Science and Engineering Research (IJOSER).

7. Project Management Institute. (2017). A guide to The Project Management Body of Knowledge (PMBOK Guide) Fourth Edition (6th Editio.). Pennsylvania: Project Management Institute, Inc.

8. Muharam, Noor. (2006). Faktor-Faktor Internal Yang Berpengaruh Dalam Perusahaan Jasa. Program Pasca Sarjana Fakultas Teknik UI, Salemba.

9. Katebi, A. And Teymourfar, R. (2017). Identification, Analysis and Response to Risk in High-Rise Building Projects in Tehran's Municipality of 22th District Based on Vikor Technique. International Journal of Civil Engineering and Technologi.

10. El-Dash, K. et al. (2006). Risk Management in the Design Phase of Large Scale Construction Project. Journal of EHAF Consultings, Cairo, Egypt.

11. Ratyaningsih, A. et al. (2018). Hazard Identification, Risk Analysis and Risk Assessment on High-Rise Building
Construction Project. AIP Conference Proceedings 1977, 020014.

12. Abhijeet, S.D. et al. (2012). Lean Techniques in the Management of The Design of an Industrial Project. Journal of Management in Engineering. ASCE.

13. Andrews, J.D. and Ridley, L.M. 2002. Application of the cause-consequence diagram method to static systems. Reliability Engineering \& System Safety, 75(1), pp.47-58.

14. Alam, Toni. (2011). Identifikasi FaktorFaktor Risiko Proyek Rancang Bangun (Design \& Build) pada PT. XYZ Yang Berpengaruh Terhadap Kinerja Waktu, Universitas Indonesia.

15. Ekaterina, Osipova. (2009). Risk Management in the Difference Phases of a Consruction Project - A Study of Actor's Involvement. Department of Civil, Mining and Environmental Engineering.

16. Ridley, L.M. and Andrews, J.D. (2009). Application of the Cause-Consequence Diagram Method to Static Systems. Journal of Department of Mathematical Sciences.

How to cite this article: Oktaviani O, Susetyo B, Bintoro BPK. Risk management model using cause and effect analysis in industrial building project. International Journal of Research and Review. 2021; 8(8): 227-235. DOI: https://doi. org/10.52403/ijrr.20210832 